\title{
A New Finding in Early $N$-Glycan Biosynthesis with Clinical Relevance
}

\author{
臨床的意義のある $N$ - 結合型糖鎖生合成の初期過程における新たな発見
}

\author{
Key Words: $N$-glycan, congenital disorders of glycosylation (CDG), steroid 5alpha-reductase 3 (SRD5A3), dolichol
}

The process of $\mathrm{N}$-glycosylation mainly consists of three steps: First an oligosaccharide precursor $\left(\mathrm{Glc}_{3} \mathrm{Man}_{9} \mathrm{GlcNAc}_{2}\right)$ is assembled on the lipid carrier dolichol-phosphate (Dol-P) on the endoplasmic reticulum (ER) membrane. Second, this glycan block is transferred to asparagine residues in the consensus sequence $N-\mathrm{X}-\mathrm{S} / \mathrm{T}$ (where $\mathrm{X}$ can be any amino acid except proline) of nascent glycoproteins by oligosaccharyl transferase. Third, the $N$-glycan is modified by subsequent trimming and elongation reactions beginning in the ER and ending in the Golgi apparatus. In humans, disruptions in $\mathrm{N}$-glycosylation lead to congenital disorders of glycosylation (CDGs), which can be diagnosed simply and reliably by a screening test of the $N$-glycosylation status of a serum protein, transferrin. Defects in the maturation and transfer of the glycan precursor, located in the ER, have been grouped as CDG type I, and disorders affecting the subsequent $N$-glycan processing steps (or affecting $O$-glycosylation) are grouped as CDG type II. Although these diseases show extremely wide symptoms and severity, several cases have been reported with primary neurological involvement including cerebellar ataxia, suggesting that cerebellar disease may be a sensitive measure of defective $\mathrm{N}$-glycosylation.

The authors identified a large consanguineous Emirati family of Baluchi (Southern Iran) origin (CVH-385) with a new autosomal recessive syndrome. All affected children manifested ocular colobomas, ichthyosis, heart defect, developmental delay, and brain malformations including cerebellar vermis hypoplasia. By performing a genomewide linkage analysis, they mapped the disease locus on chromosome $4 \mathrm{q} 12$ containing 42 genes, which were then screened for mutation with bidirectional sequencing. The steroid $5 \alpha$-reductase 3 (SRD5A3) gene turned out to have a molecular rearrangement with a homozygous 3-bp deletion and a 10-bp insertion resulting in a predicted stop codon at amino acid 96. The phenotypic similarity with several CDGs prompted a test for the $\mathrm{N}$-glycosylation status of transferrin using mass spectrometry. CVH-385 showed a very clear defect with approximately $45 \%$ of monoglycosylated transferrin, suggesting that the SRD5A3 mutation results in a CDG type I.

To begin to understand the biochemical function of SRD5A3, the authors examined a homolog in yeast. A yeast
$N$ - 結合型糖鎖の生合成は主に次の 3 つのステップからな る。まず小胞体膜上の脂質輸送体ドリコールリン酸に 14 個 の単糖が逐次付加され、オリゴ糖前駆体が形成される。次に、 この前駆体が、タンパク質の $N$-結合型糖鎖付加のコンセンサ 又配列 (N-X-S/T、ここで X はプロリン以外のアミノ酸) 中 のアスパラギン残基にオリゴ糖転移酵素によって転移される。 そして、このタンパク質上のオリゴ糖から一旦グルコース残 基とマンノース残基が切り離された後、再び、糖鎖は伸長さ れる。ヒトに㧍いては、 $N$ - 結合型糖鎖生合成の異常によって 糖タンパク質糖鎖不全症候群 (CDG) が引き起こされるが、そ の診断には、血中トランスフェリンの $N$ - 結合型糖鎖が信頼性 の高い指標として簡便に使われる。小胞体での糖前駆体の合 成の異常によって引き起こされるものは、CDG-I、また、その 後の合成過程あるいは $O$ - 結合型糖鎖合成過程の異常によって 引き起こされるものは、CDG-II と分類される。患者ごとに、 症状は多岐に渡り、その重篤度も異なるが、いくつかの患者は、 小脳性失調症を含む神経症状を主症状としており、小脳性の 疾患は $N$-結合型糖鎖生合成の異常に鋭敏に反応して生じてい るのかもしれない。

著者らは、新規常染色体劣性症候群を発症している南部 イランバルチ地方に起源を持つエミレーツの大きな血族家系 (CVH-385) を見い出した。発症している幼児には、心疾患、発 達遅延、そして、小脳虫部低形成などの脳奇形が見られた。 ゲノム規模の連鎖解析によって、彼らは病因となる 4 番染色 体長腕 (4q12) 中の 42 遺伝子を含む領域を特定し、それら 42 遺伝子の塩基配列を解析した。その結果、ステロイド $5 \alpha$ - 還 元酵素 (SRD5A3) 遺伝子中にホモの 3 塩基の欠失と 10 塩基の 挿入が存在し、それによって 96 番目のアミノ酸が終止コドン に変化していることが分かった。さらに、患者の症状が CDG 患者のそれと似ていたことから、質量分析計によってトラン スフェリンの $N$ - 結合型糖鎖を解析したところ、通常すべての トランスフェリンは二本の $N$ - 結合型糖鎖をもつが、患者試料 では一本鎖の $N$ - 結合型糖鎖をもつトランスフェリンが全体の $45 \%$ 検出された。以上より、SRD5A3 に抢ける変異がこの家 系に抢ける CDG-I の原因遺伝子であることが示唆された。

SRD5A3 の生化学的な機能を明らかにするために、著者 らは SRD5A3 の酵母の相同遺伝子を解析した。DFG10 遺伝 
mutant for the DFG10 gene, called dfg10-100, had been previously isolated by a genetic screen for mutants defective for filamentous growth (dfg). DFG protein shows 25\% amino acid identity with the human SRD5A3 protein. Interestingly, the authors found the yeast mutant also showed a defect in $\mathrm{N}$-glycosylation. In humans, five homologous genes compose the steroid $5 \alpha$-reductase family, including the wellcharacterized SRD5A1 and SRD5A2 involved in testosterone reduction and the less well-characterized SRD5A2L2, GPSN2, SRD5A3. Among these five, only SRD5A3 rescued the defect of $\mathrm{N}$-glycosylation in the mutant, dfg 10-100. These data suggest that the function of SRD5A3 is conserved evolutionarily and that SRD5A3 specifically has a role in $\mathrm{N}$-glycosylation compared with other family members. In mice, deletion of the $\operatorname{Srd5A3}$ gene disrupted $\mathrm{N}$-glycosylation and resulted in embryonic lethality. Whole-transcriptome analysis of mouse embryos revealed that among the 50 most upregulated transcripts, $20 \%$ are involved in the regulation of the unfolded protein response or are activated in this pathway. Therefore, Srd5A3 is required for ER protein folding, a primary role of $\mathrm{N}$-glycans during development.

So, what is the molecular function of Srd5A3 protein in $N$-glycosylation? The absence of whole glycan chains on proteins indicated that the metabolic block occurred in the $\mathrm{N}$-glycosylation pathway, altering synthesis or transfer of the glycan part of lipid linked oligosaccharide (LLO), to recipient proteins. Epitope-tagged SRD5A3 localized predominantly to the ER, where LLO synthesis occurs. Metabolic radiolabeling experiments using the cells from the patients showed no major structural abnormalities in LLO. However, a severe reduction in the amount of newly synthesized LLO in four of the five patients tested was compared to the control, suggesting that impairment of the $\mathrm{N}$-glycosylation pathway occurs prior to the glycan transfer step. The enzymatic activities of GlcNActransferases producing Dol-PP-GlcNAc and Dol-PP-GlcNAc $c_{2}$ in all SRD5A3 deficient patient samples were significantly lower than the control without addition of exogenous Dol-P. However, exogenous addition of Dol-P rescued the deficiencies, indicating that the patients have a defect in Dol or Dol-P biosynthesis.

The unidentified polyprenol reductase enzyme in the Dol-P biosynthetic pathway made SRD5A3 a likely candidate for this function. The LC-MS analysis showed that polyprenol was not detected in any samples of wildtype origin, but easily detected in the yeast and mouse mutants, suggesting an inhibition of the polyprenol reduction step. They also found an increased level of polyprenoids in patients' samples compared with the control. However, the presence of residual dolichol in the mutants lacking this gene suggested the existence of an unexpected alternative pathway for dolichol de novo biosynthesis. Nonetheless, transformation of the
子の酵母変異株 dfg10-100 は、糸状増殖に障害をもつ変異体 のスクリーニングに抢いて単離された。酵母 DFG タンパク質 は、ヒトの SRD5A3 タンパク質に対してアミノ酸配列上 25\% の相同性を持つ。興味深いことに、この酵母変異株もまた $N$ 結合型糖鎖不全を呈していた。ヒトに扔いては、ステロイド $5 a$ - 還元酵素ファミリーは 5 つの遺伝子からなり、SRD $5 A 1$ と SRD5A2 については既に研究が進んで扔り、テストステ ロンの還元を担っていることが示されているが、SRD5A2L2、 GPSN2、およびSRD5A3 については研究があまり進んでいな かった。これら 5 つの遺伝子のうち、酵母変異株 dfg10-100 にSRD5A3 を発現させた場合にのみ、その $N$-結合型糖鎖不 全が解消された。これらの結果は、SRD5A3 の機能が進化上 よく保存されて扔り、かつ、ステロイド $5 a$ - 還元酵素ファミ リーの中で SRD5A3 のみが特異的に $N$ - 結合型糖鎖に関与し ていることを示唆している。マウスにおいては、Srd5A3 の欠 損は $N$ - 結合型糖鎖不全を生じ、胎生致死となった。マウス胚 の全トランスクリプトーム解析によると、発現の上昇した 50 の遺伝子のうち、20\% は小胞体ストレス応答の制御あるいは 活性化に関係するものであった。それゆえ、Srd5A3 は、発生 期の $N$ - 結合型糖鎖の主要な機能である小胞体に扔けるタンパ ク質のフォールディングに必要であることが示唆された。

それでは、Srd5A3 は $N$-結合型糖鎖合成においてどのよ うな分子機能を担っているのであろうか? タンパク質上の $N$ 結合型糖鎖全体が消失していることから、 $N$ - 結合型糖鎖合成 初期の脂質結合性オリゴ糖 (LLO) の糖鎖部分の合成過程か、 受け手となるタンパク質への転移過程に異常があるのではな いかと考えられた。実際、SRD5A3 はLLO の合成される場 である小胞体に主に局在することが示された。患者組織から 樹立された細胞を用いた代謝標識実験によれば、LLO の構造 自体には異常が見られなかったが、調べた 5 人の患者のうち 4 人に掠いて LLO の量が健常人に比べて著しく減少してい ることが判明し、生合成上、糖鎖の転移よりも前の過程に異 常があることが示唆された。さらに、ドリコール -二リン酸 -GlcNAc あるいはドリコール -二リン酸 - $\mathrm{GlcNAc}_{2}$ を生成する GlcNAc 転移酵素活性を調べると、実験系にドリコール -リン 酸を加えない場合には、患者標本において有意にこの活性が 弱く、実験系にドリコール - リン酸を加えた場合には、この差 がなくなることが分かった。これは、ドリコールあるいはド リコール - リン酸の生合成過程に異常があることを示唆してい る。

ここで、SRD5A3 が、ドリコール - リン酸の生合成過程 に打いて、未だに同定されていない、ポリプレノール還元酵 素活性本体である可能性が浮上した。酵母抄よびマウス試料 の液体クロマトグラフ質量分析に抏いて、ポリプレノールが、 野生型では検出されないのに対し、Srd5A3 の変異体におい ては容易に検出され、これによりポリプレノールの還元過程 が阻害されていることが示唆された。また、患者血清中のポ リプレノール類レベルが上昇していることも明らかになった。 しかしながら、変異体においてもドリコールは残存していた ことから、未だに同定されていないドリコールの生合成経路 の存在が示唆された。酵母変異体 dfg10-100 にヒト SRD5A3 
yeast mutant, dfg10-100, with the SRD5A3 gene efficiently and specifically corrected the accumulation of polyprenol. Furthermore, the lysates of HEK293T cells overexpressing SRD5A3 reduced polyprenol to dolichol more efficiently than those of control cells. These data strongly suggest that SRD5A3 is likely to be the long-sought polyprenol reductase.

What a nice and influential paper! This work is very important not only because the authors found a gene responsible for a new type of CDG-I, which may lead to clinical applications, but also because they provided novel insight into the early steps of the $\mathrm{N}$-glycosylation pathway which are evolutionarily conserved. Although they explored the defects in the $N$-glycosylation pathway in the present study, dolichol is also necessary for the synthesis of $O$-mannose glycans, $C$-mannosylation, and glycophospholipid anchor synthesis. These defects might also play a role in the pathology. Therefore, it will be interesting to explore the how this mutation affects these types of glycosylation.[V. Cantagrel et al. (2010) Cell 142, 203-217].

Reported by Hideyuki Takeuchi

Dept. of Biochemistry and Cell Biology, Stony Brook University

Stony Brook, NY 11794-5215, USA

E-mail: htakeuchi@ms.cc.sunysb.edu

FAX:1-631-632-8575
を発現させると、ポリプレノールの蓄積が効率よく、特異的 に解消された。さらに、SRD5A3 を過剩発現させた HEK293T 細胞の細胞抽出物によってポリプレノールがドリコールに 対照に比べてより効率よく還元された。これらの結果より、 SRD5A3 が長い間同定されていなかったポリプレノール還元 酵素であることが強く示唆された。

本研究は大変質が高く、波及効果も大きいだろう。著者 らが臨床に応用できる可能性もある新しいタイプの CDG-I の 原因遺伝子を突き止めただけでなく、進化上よく保存されて いる $N$ - 結合型糖鎖合成の初期過程に関する新たな洞察を与え ているが故に学問的にも大変重要である。ひとつ違った見方 を付け加えるならば、著者らは本研究において $N$ - 結合型糖鎖 の不全に着目したが、ドリコールは $O$ - マンノース糖鎖、C- 、 ンノース糖鎖、さらには GPI アンカーの合成にも必要である ことが知られて抢り、それらの異常が病態に結びついている 可能性もあるのではないだろうか。ゆえに、SRD5A3 の変異 がこれらの糖鎖の合成にどの程度影響しているか調べること も興味深い課題である。[V. Cantagrel et al. (2010) Cell 142, 203217]

竹内 英之

ストーニーブルック大学 